\title{
Morphological characterization and diversity of tadpoles (Amphibia: Anura) at Emas National Park and its surrounding, Goiás State, Brazil
}

\author{
Gabriela Alves-Ferreira $^{1^{*}}$, Ingrid Beatriz Ferreira da Paixã $o^{2}$ \& Fausto Nomura ${ }^{3}$ \\ ${ }^{1}$ Universidade Estadual de Santa Cruz, Tropical Herpetology Lab, Programa de Pós- Graduação em Ecologia e \\ Conservação da Biodiversidade. Rodovia Jorge Amado, km 16, 45662-900 Ilhéus, Bahia, Brasil. \\ ${ }^{2}$ Universidade Federal de Uberlândia. Laboratório de Ecologia de Mamiferos (LEMA). Programa de Pós- \\ graduação em Ecologia e Conservação dos Recursos Naturais. Avenida Pará, Umuarama, 388405320 \\ Uberlândia, Minas Gerais, Brasil. \\ ${ }^{3}$ Universidade Federal de Goiás. Laboratório de Ecologia e Funcionamento de Comunidades. Departamento \\ de Ecologia. Rodovia Nerópolis- Goiânia, Km 5, 74001-970 Goiânia, Goiás, Brasil. \\ *Corresponding author: gabriela-alves77@hotmail.com
}

ALVES-FERREIRA, G., FERREIRA DA PAIXÃO, I.B., NOMURA, F. Morphological characterization and diversity of tadpoles (Amphibia: Anura) at Emas National Park and its surrounding, Goiás State, Brazil. . Biota Neotropica 21(4): e20201178. https://doi.org/10.1590/1676-0611-BN-2020-1178

\begin{abstract}
Tadpoles are abundant in the environments in which they occur and remain in aquatic habitats for longer periods than adults, being relatively easier to collect. Despite the increase in tadpole research in the past decade, our understanding of its morphological diversity remains limited. Here, we provide morphological characterizations for larvae of 15 anuran species that occur at Emas National Park (ENP) and its surroundings, in Goiás, and compare them with descriptions available in the literature for other locations. We also present an update of the list of anuran species known to the ENP, based on tadpole sampling. We found tadpoles from 15 anuran species, of which five represent new records for the park. Many species showed variations in morphological characters when compared with descriptions available in the literature for other locations, reinforcing the importance of describing larvae from different populations. Through the exploration of morphological characters, it is possible to make inferences about the functional diversity of the larvae and questions related to the homology of characters, in addition to assisting in the identification and taxonomic distinction of species. Studies with tadpole communities can generate key information about the factors that drive the anurans' richness and distribution and can provide support for establishing more consistent conservation strategies and management plans.
\end{abstract}

Keywords: External Morphology; Cerrado; Species survey; Conservation unity; Tropical anurans.

\section{Caracterização morfológica e diversidade de girinos (Amphibia: Anura) no Parque Nacional das Emas e seus arredores, estado de Goiás, Brasil}

Resumo: Os girinos são abundantes nos ambientes que ocorrem e permanecem nos habitats aquáticos por períodos de tempo mais longos que os adultos, sendo relativamente mais fáceis de coletar. Apesar do aumento da pesquisa com girinos na última década, nossa compreensão sobre sua diversidade morfológica ainda permanece limitada. Aqui, fornecemos caracterizações morfológicas para larvas de 15 espécies de anuros que ocorrem no Parque Nacional das Emas (PNE), Goiás, e comparamos com descrições disponíveis na literatura para outras localidades. Apresentamos também uma atualização da lista de espécies de anuros conhecidos para o PNE, com base na amostragem de girinos. Encontramos larvas de 15 espécies de anuros, das quais cinco representam novos registros para o parque. Muitas espécies apresentaram variações nos caracteres morfológicos quando comparamos com descrições disponíveis na literatura para outras localidades, reforçando a importância da descrição de larvas de diferentes populações. Através da exploração de caracteres morfológicos é possível realizar inferências sobre a diversidade funcional das larvas e questões relativas à homologia de caracteres, além de auxiliar na identificação e distinção taxonômica das espécies. Estudos com comunidades de girinos podem gerar informações importantes sobre os fatores que impulsionam a riqueza e a distribuição dos anuros e, podem fornecer suporte para o estabelecimento de estratégias de conservação e planos de manejo mais consistentes.

Palavras-chave: Morfologia externa; Cerrado; Levantamento de espécies; Unidade de conservação; Anuros tropicais. 


\section{Introduction}

The biphasic life cycle is one of the main characteristics that differentiate amphibians from the rest of terrestrial vertebrates. Most of the group's representatives have a larval phase, which for most species is aquatic, and an adult phase, usually terrestrial (Duelman \& Trueb 1986). The numerous morphological and behavioral adaptations allow tadpoles to live in different types of habitat, such as puddles, phytotelmata, or streams (Altig \& McDiarmid 1999). As anuran larvae need to remain in these environments until development is complete, their location may be more predictable and more accessible for capture than breeding adult frogs (Lips \& Savage 1996, Altig \& McDiarmid 1999, Silva 2010, Mascarenhas et al. 2016).

Despite the relative ease of collection, tadpoles are rarely targets for inventories conducted in the Neotropics, with most studies using the adult phase and acoustic information (Maladozzo et al. 2017). The main obstacle for the increase in the studies using anuran larvae is the difficulty of identification (Rossa-Feres \& Nomura 2006, Provete et al. 2012). Although taxonomic keys are a tool that undoubtedly facilitates access to species diversity, the morphological characterizations of sampled populations have become increasingly necessary, as in addition to helping to identify larvae, it allows inferences to be made about phylogenetic relationships (Altig \& McDiarmid 1999, Vences et al. 2010, Schulze et al. 2015, Gehara et al. 2014). Despite the importance, studies with this purpose still represent a gap for the tropical region, particularly for Brazil, where around 793 species of anurans with aquatic larvae are known (Rossa-Feres et al. 2015), but only $60 \%$ have the larval phase described (Provete et al. 2012).

The scenario worsens when considering the high morphological plasticity of the tadpoles. Adapting to the diverse selective pressures exerted by habitats requires tadpoles' high adaptive capacity and phenotypic plasticity (Lind \& Johansson 2007, Marques \& Nomura 2018, Marques et al. 2019). The phenotypic plasticity can cause a high variation in certain morphological traits in response to local environmental pressures, and consequently, can mislead the correct taxonomic identification of the anuran larvae. We must understand better how tadpoles' morphological diversity is affected by geographic variation and, to achieve this goal, we need to increase the number of anuran populations that have their larvae described, providing characterizations even for species that already have a formal description (Gehara et al. 2014).

Currently, in the Cerrado, about 212 anuran species are known (Valdujo et al. 2012), of which more than half are endemic (51\%, Colli et al. 2002). However, the morphological characterizations for the species that occur in the biome are scarce, and even those that already have a formal description, are restricted to specific locations (e.g. northwest region of São Paulo, Rossa-Feres \& Nomura 2006). The Emas National Park (ENP), located in the southwest region of Goiás, is considered one of the largest preservation areas in the Cerrado, where 25 anuran species are known (14 of them in larval phase, Kopp et al. 2010). However, morphological characterizations for larvae that occur in the park are currently unavailable.

Here, we provide morphological characterizations for larvae of 15 anuran species that occur at ENP and surrounding and compare them with descriptions already available in the literature. We also present an update of the list of anuran species known for the park, based only on tadpole sampling. We hope that the information provided by this study may assist in future research on the anurofauna of Cerrado and assist in understanding the morphological diversity of anuran larvae.

\section{Material and Methods}

Sampling was carried out at breeding sites located at Emas National Park and surrounding $\left(17^{\circ} 49^{\prime}, 18^{\circ} 28^{\prime} \mathrm{S}\right.$ and $\left.52^{\circ} 39^{\prime}, 53^{\circ} 10^{\prime} \mathrm{W}\right)$, southwest of Goiás, Brazil (Figure 1). ENP harbors a variety of vegetation types such as "cerrado sensu stricto" (dense Savannah), "Murundu" fields (Termite mounds), "Veredas" (Palm swamps), Riparian and Seasonal Forests (Ramos-Neto \& Pivello 2000). The study area also has a high heterogeneity of water body types that vary between lotic or lentic environments and permanent or temporary. The surroundings of ENP have been under constant pressure due to intense agricultural activities and the farming of soybean and sugarcane (IBDF 1981).

We visited 23 water bodies during the rainy seasons (October to March) from 2014-2015, 2015-2016, and 2016-2017 (see table S1 in supplementary material). Waterbody margins were sampled using a conical dip net ( $3 \mathrm{~mm}^{2}$ mesh), sweeping the environment for an hour or until a complete turn in its perimeter was completed. Although this sampling method is one of the most used for collecting tadpoles, the physical structure of water bodies can affect their efficiency. In deep pools, for example, the reach of the dip net is often limited to only shallow and marginal portions of the pond (Silva 2010, Morais et al. 2011).

The collected tadpoles were anesthetized with 5\% lidocaine solution and subsequently, fixed and preserved in $10 \%$ formalin solution. The identification of the specimens was made based on Rossa-Feres \& Nomura (2006). This taxonomic key includes the most common anuran species found throughout the Cerrado. Species that were not found in this taxonomic key were identified by comparisons with published articles. Digital images of tadpoles were taken with a DFC550 lens coupled to a Leica M205A stereomicroscope. Taxonomic nomenclature followed Frost (2020). Testimony material was deposited at the Zoological Collection of the Federal University of Goiás (ZUFG, for more details, see Table S2 in supplementary material).

We used around 10 tadpoles between stages 34 and 40 to characterize species morphology (sensu Gosner 1960). The use of tadpoles at, or close to, the developmental stage 37 to characterize morphological variation reduces allometric differences (Grosjean 2005). Morphological description and terminology follow Altig \& McDiarmid (1999) and Pezzuti (2011), the nomenclature of oral apparatus follows Altig (1970) and classification of ecomorphological guilds follows Altig \& Johnston (1989). Coloration classification was made based on fixed specimens.

Estimated species richness and confidence intervals were calculated from a species accumulation curve generated from 5000 randomizations (Lande et al. 2000) in EstimateS 9.1.0 (Colwell 2016). A species accumulation curve records the total number of species collected over a sampling effort (Gotelli \& Colwell 2001), so it can be used to indicate whether the sampling was sufficient to estimate the species number in a community (Cullen et al. 2012). A sample-based accumulation curve allows the calculation of confidence intervals for all points on the curve, facilitating comparisons between areas (Colwell et al. 2004). The first-order Jackknife estimator (Jackknife 1) was used to estimate and compare local and expected richness since it is the best method to simulate curves from empirical data (Walther \& Morand 1998). The Jackknife 1 estimates richness by adding the number of observed species to a parameter calculated from the number of rare species found in a given sample ("singletons") and the total sample number (Colwell et al. 2004). 


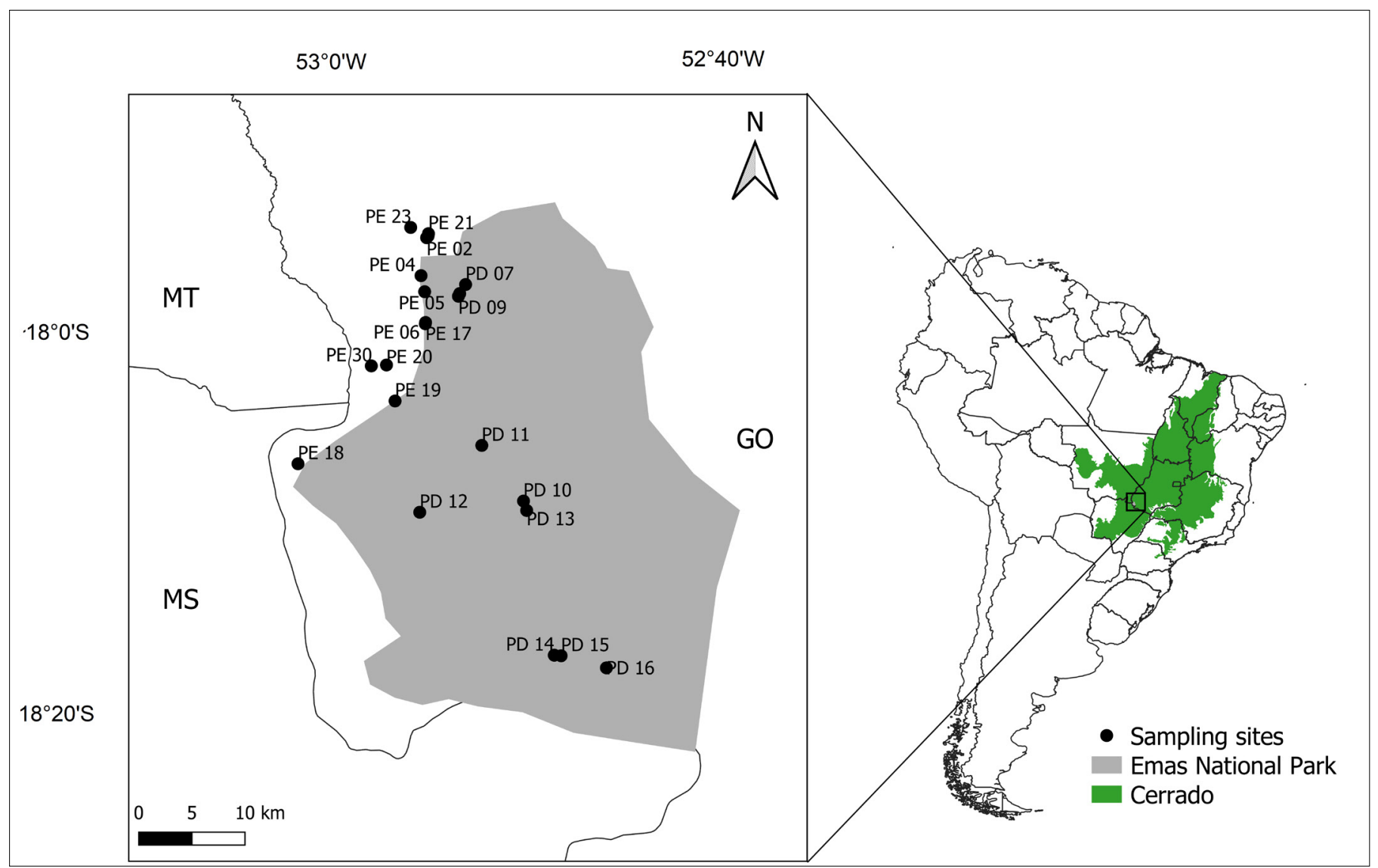

Figure 1. Location of sampled water bodies at ENP and surroundings, Goiás, Brazil. The green area represents the remnants vegetation cover of the Cerrado and the gray area represents the area of ENP, the black line is the border between the states of Goiás, Mato Grosso, and Mato Grosso do Sul and black dots are sampling sites PD refers to sampling points located within the ENP and PE to points located around the ENP.

\section{Results}

We collected 7.640 individuals of 15 anuran species distributed in six genera and three families (see Table S3 in supplementary material). We recorded five species not found previously and represent new records for the study area: Dendropsophus nanus, Scinax aff. similis, Physalaemus marmoratus, Elachistocleis sp. and Elachistocleis cesarii. The families with the largest number of species were Hylidae and Leptodactylidae (seven and six species, respectively). Microhylidae family presented only two species. The most abundant species was Scinax aff. similis with 3234 individuals, representing $42.32 \%$ of the total specimens collected.

Larvae were classified into five ecomorphological guilds (Figure 2), being represented by macrophagous tadpoles (Dendropsophus nanus, Dendropsophus sp.), benthic tadpoles (Boana albopunctata, Leptodactylus fuscus, L. podicipinus, Physalaemus cuvieri, P. nattereri, P. marmoratus), suspension feeder tadpoles (Elachistocleis cesarii, Elachistocleis sp.), carnivore tadpoles (Leptodactylus labyrinthicus) and nektonic tadpoles (Scinax aff. similis, S. fuscomarginatus, S. fuscovarius, Dendropsophus minutus).

Species accumulation curves for the study area showed a strong tendency to stabilize (Figure 3). However, as confidence intervals of observed and expected richness curves did not overlap, we infer that we have recorded fewer species than expected, which may be a consequence of using a single sampling technique to sampling anurans (only larval phase).

\section{Morphological characterization and comments}

\section{Hylidae Rafinesque, 1815}

Dendropsophus sp., figure (4A).

Specimens examined. 10 tadpoles, stages 34 to 39 .

Characteristics. Body compressed, elliptical in dorsal view and depressed triangular in lateral view. Snout pointed in dorsal view and sloped in lateral view. Eyes lateral dorsolaterally directed. Nares circular laterally positioned with opening anterolaterally directed without projection. Spiracle lateroventral, sinistral posterodorsally directed and fully fused to the body wall. Vent tube dextral positioned at the origin of the ventral fin. Oral disc anteroventral modified to a protractile tube. Absence of emargination, marginal and submarginal papillaes. Tooth row formula absent. Absence of upper and lower jaw sheaths. Dorsal and ventral fins low with slightly convex margin emerging at ventral tube level. Coloration spotted or marbled with angular stains, muscle tail slightly crosslinked by melanophores, tail with coloration transparent.

Notes. This species has been referred to in other works as Dendropsophus sp. (gr. microcephalus) (e.g. Melo et al., 2013) and as D. jimi (Marques et al. 2019, supp. Information; Vaz-Silva et al. 2020). However, its distribution is not yet recognized in the Goiás State, although at least one population was reported in Brasília municipality (Frost, 2020). Tadpoles associated with Dendropsophus sp. have larger bodies, in comparison with the tail length, higher dorsal fins, and longer snouts than tadpoles of D. nanus.

Dendropsophus minutus (Peters 1872), figure (4B)

Specimens examined. 10 tadpoles, stages 34 to 38 . 


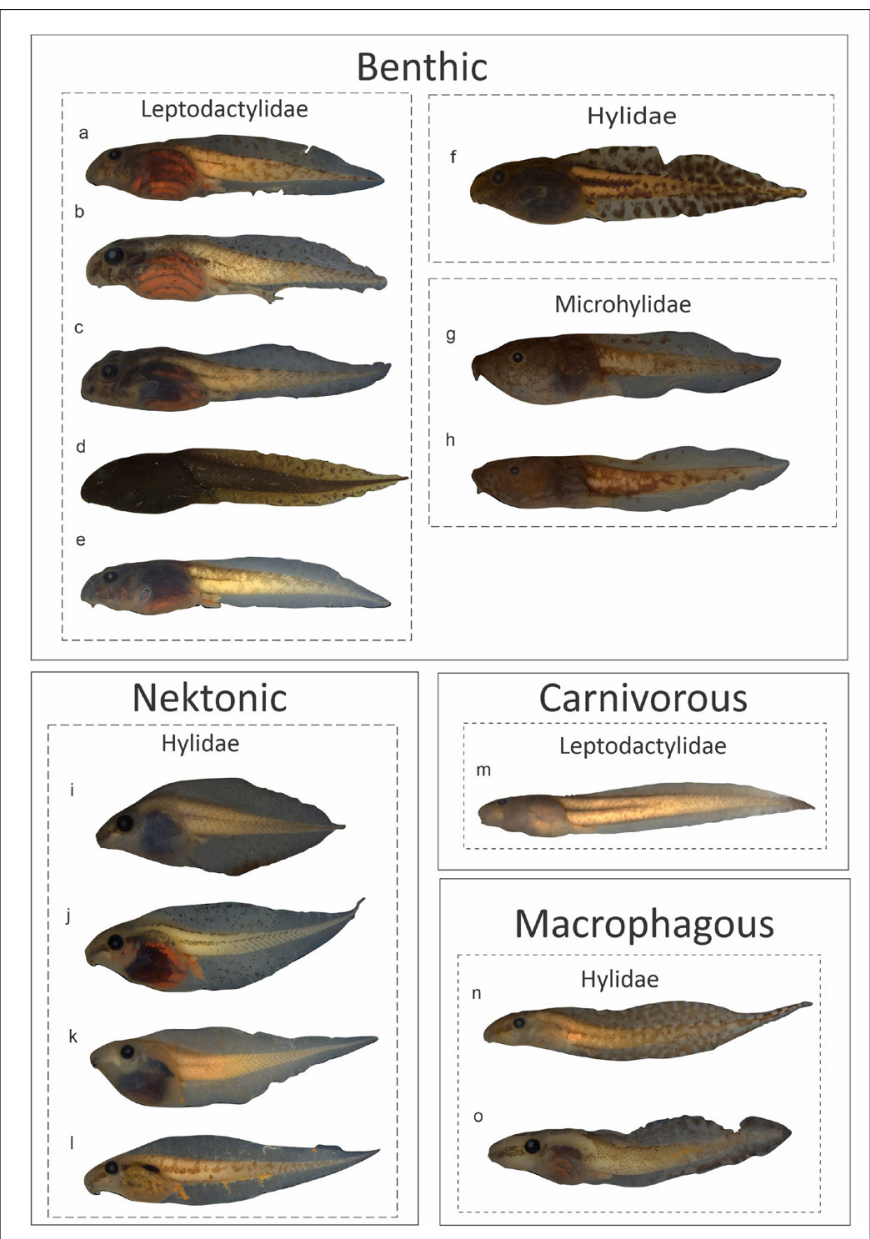

Figure 2. Ecomorphological guilds according to McDiamird \& Altig (1999) for tadpoles found at ENP and its surroundings: a) Physalaemus nattereri; b) Physalaemus cuvieri; c) Physalaemus marmoratus; d) Leptodactylus podicipinus; e) Leptodactylus fuscus; f) Boana albopunctata; g) Elachistocleis sp.; h) Elachistocleis cesarii; i) Dendropsophus minutus; j) Scinax aff. similis; k) Scinax fuscovarius; 1) Scinax fuscomarginatus; m) Leptodactylus labyrinthicus; n) Dendropsophus nanus; o) Dendropsophus sp.

Characteristics. Body compressed, ovoid in dorsal view and triangular in lateral view. Snout rounded in dorsal view and sloped in lateral view. Eyes lateral laterally directed. Nares circular dorsolaterally positioned with opening posterodorsally directed without projection. Spiracle lateroventral, sinistral, posterodorsally directed, centripetal wall present, fully fused to the body wall. Vent tube dextral, with a free distal edge. Oral disc anteroventral with keratinized structures, emargination absent, marginal papillae present and submarginal papillae absent. Tooth row formula 0/1. Upper jaw sheath "arc" shaped and lower jaw sheath "U" shaped. Dorsal and ventral fins high with convex margin emerging at ventral tube level. Coloration and muscle tail slightly crosslinked by melanophores, tail with coloration transparent.

Notes. The tadpoles we describe are similar to those described for other populations, differing in a few characters: body and snout shape, tooth row formula, and fin height. The population described by Dubeux et al. (2020), collected in the municipalities of Limoeiro de Anadia, Alagoas State, Brazil (stages 30 to 34) and Macaíba, Rio Grande do Norte State, Brazil (stage 35 to 39), had an elliptical elongated body in dorsal view and truncated snout in lateral view. The position of the oral disk is anterior, and the tooth row formula is $1 / 2$. The tadpoles described by Rossa-Feres \& Nomura (2006), collected in Nova Itapirema and Macaúbas, São Paulo State, Brazil (stages 37 to 40), had an oval body in dorsal view and nostrils positioned laterally, and a low dorsal fin inclination $\left(<30^{\circ}\right)$. The sampled population described by Schulze et al. (2015), collected in San Sebastian, Bolívia (stages 36 to 41), had a different tooth row formula, with tadpoles presenting LTRF 0/2.

Dendropsophus nanus (Boulenger 1889), figure (4C)

Specimens examined. 10 tadpoles, stages 34 to 39 .

Characteristics. Body compressed, elliptical in dorsal view and depressed triangular in lateral view. Snout rounded in dorsal view and sloped in lateral view. Eyes lateral laterally directed. Nares oval laterally positioned with opening anterolaterally directed without projection. Spiracle lateroventral, sinistral, posterodorsally directed, centripetal wall present, fully fused. Vent tube dextral, positioned at the origin of the ventral fin. Oral disc ventral modified to a protractile tube, marginal and submarginal papillaes absent. Tooth row formula absent. Upper jaw sheath "arc" shaped and lower jaw sheath "V" shaped. Dorsal and ventral fins low with slightly convex margin emerging at vent tube level. Coloration spotted or marbled with rounded stains, muscle tail spotted or marbled with angular stains, tail with homogeneous coloration.

Notes. The tadpoles described by Rossa-Feres \& Nomura (2006), collected in Nova Itapirema, São Paulo State, Brazil (stages 37 to 40), have some differences from the tadpoles characterized in this study. Those tadpoles had an oval body and a pointed snout in dorsal view, an anteroventral oral disc, and an obtuse dorsal fin, regarding its angle of emergence. The population collected in San Sebastian, Bolivia (stages 37 and 38) and described by Schulze et al. (2015) had a compressed body, ovoid body in dorsal view and a "tapered" snout in dorsal view.

Scinax aff. similis (Cochran 1952), figure (4D)

Specimens examined. 10 tadpoles, stages 34 to 38 .

Characteristics. Body compressed, elliptical in dorsal view and triangular in lateral view. Snout truncate in dorsal view and sloped in lateral view. Eyes lateral laterally directed. Nares rounded/circular, dorsolaterally positioned with opening dorsolaterally directed without projection. Spiracle lateroventral, sinistral, with posterodorsally directed opening, centripetal wall fused with the body wall. Vent tube dextral, fused to the ventral fin. Oral disc anteroventral, with keratinized structures, emargination absent, marginal and submarginal papillaes present. Tooth row formula $2(1,2) / 3(1)$. Upper jaw sheath " $M$ " shaped and lower jaw sheath "V" shaped. Dorsal and ventral fins high with convex margin emerging anterior to the ventral tube. Coloration spotted or marbled with angular stains, muscle tail slightly crosslinked by melanophores, tail with coloration transparent.

Notes. The population described by Alves \& Carvalho e Silva (1999), from the Rio de Janeiro State, Brazil (stage 37), had oval nostrils positioned dorsally and LTRF 2(2)/3(1). The tadpoles described by Rossa-Feres \& Nomura (2006), from Nova Itapirema, São Paulo State, Brazil (stages 37 and 38), had a rounded snout in dorsal view, a spiracle positioned posterodorsally and tooth row formula 2(2)/3(1), while tadpoles from ENP had the nostril posterodorsally directed and the LTRF 2(1,2)/3(1). Populations of this species in the Goiás State have been treated as Scinax aff. similis by Frost (2021) and Vaz-Silva et al. (2020) because of the taxonomic uncertainty (N.N. Dias, pers. comm.).

Scinax fuscomarginatus (Lutz 1925), figure (4E)

Specimens examined. 10 tadpoles, stages 34 to 39. 


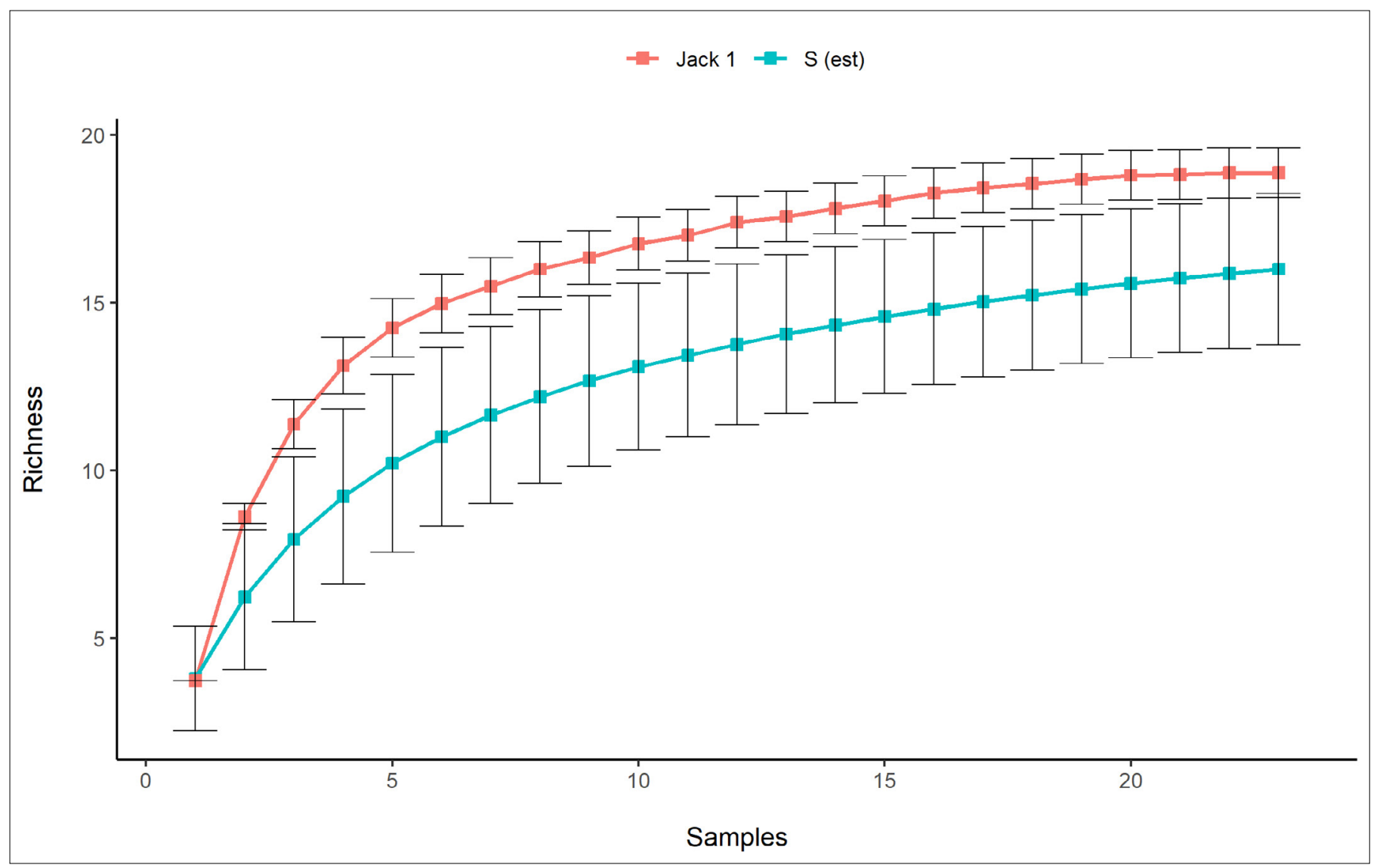

Figure 3. Species accumulation curve of anuran species at larval phase found at ENP. Vertical bars are confidence intervals at $95 \%$.

Characteristics. Body compressed, rounded in dorsal view and depressed triangular in lateral view. Snout truncates in dorsal view and rounded in lateral view. Eyes lateral laterally directed. Nares circular dorsolaterally positioned with opening dorsolaterally directed without projection. Spiracle lateroventral, sinistral, posterodorsally directed; centripetal wall fused to the body wall. Vent tube dextral, fused to the ventral fin. Oral disc ventral, with keratinized structures, ventral emargination, marginal papillae present and submarginal papillae absent. Tooth row formula 2(2)/3(1). Upper jaw sheath "arc" shaped and lower jaw sheath "U" shaped. Dorsal and ventral fins medium with convex margin emerging anterior to the vent tube. Coloration slightly crosslinked by melanophores, muscle tail spotted or marbled with angular stains, tail with coloration transparent.

Notes. The population described by Rossa-Feres \& Nomura (2006) from Nova Itapirema, São Paulo State, Brazil, had an oval body and a rounded snout in dorsal view, anteroventral oral disc, dorsal fin with an obtuse angle of emergence, originating in the anterior third of the body.

Scinax fuscovarius (Lutz 1925), figure (4F)

Specimens examined. 10 tadpoles, stages 35 to 38 .

Characteristics. Body compressed, elliptical in dorsal view and triangular in lateral view. Snout rounded in dorsal view and sloped in lateral view. Eyes dorsal, dorsolaterally directed. Nares oval, dorsolaterally positioned with opening laterally directed without projection. Spiracle lateroventral, sinistral, posteriorly directed, centripetal wall fused to the body wall. Vent tube dextral, fused to the ventral fin. Oral disc anteroventral with keratinized structures, lateral emargination, marginal papillae present and submarginal papillae present. Tooth row formula 2(2)/3(1). Upper jaw sheath "arc" shaped and lower jaw sheath "V" shaped. Dorsal and ventral fins high with convex margin emerging at ventral tube level. Coloration and muscle tail slightly crosslinked by melanophores, tail with coloration transparent.

Notes. The tadpoles described by Rossa-Feres \& Nomura (2006) from the northwest region of the São Paulo State, Brazil, differ from the population that we described by an oval body in dorsal view, eyes directed laterally and an upper "M" shaped sheath. The sampled population described by Schulze et al. (2015), collected in San Sebastián and Estancia Büchler, Bolívia (stages 32 to 38), had a body compressed, ovoid in dorsal view, eyes directed laterally, and a spiracle with directed posterodorsally.

Boana albopunctata (Spix 1824), figure (4G)

Specimens examined. 10 tadpoles, stages 34 to 40.

Characteristics. Body depressed, elliptical in dorsal view and depressed rounded in lateral view. Snout oval in dorsal view and rounded in lateral view. Eyes dorsal, dorsolaterally directed. Nares reniform, dorsally positioned with opening dorsolaterally directed with a large projection. Spiracle lateral, sinistral, posteriorly directed, centripetal wall present, large free end. Vent tube dextral, with a free distal edge. Oral disc ventral, with keratinized structures, ventral emargination, marginal papillae present and submarginal papillae absent. Tooth row formula 2(1,2)/ 3(1). Upper jaw sheath "arc" shaped and lower jaw sheath "U" shaped. Dorsal fin medium with slightly convex margin emerging at ventral tube level. Ventral fin low with margin parallel to the longitudinal axis of the tail muscle emerging at ventral tube level. Coloration spotted or marbled with rounded stains, muscle tail spotted or marbled with angular stains, tail with coloration transparent. 

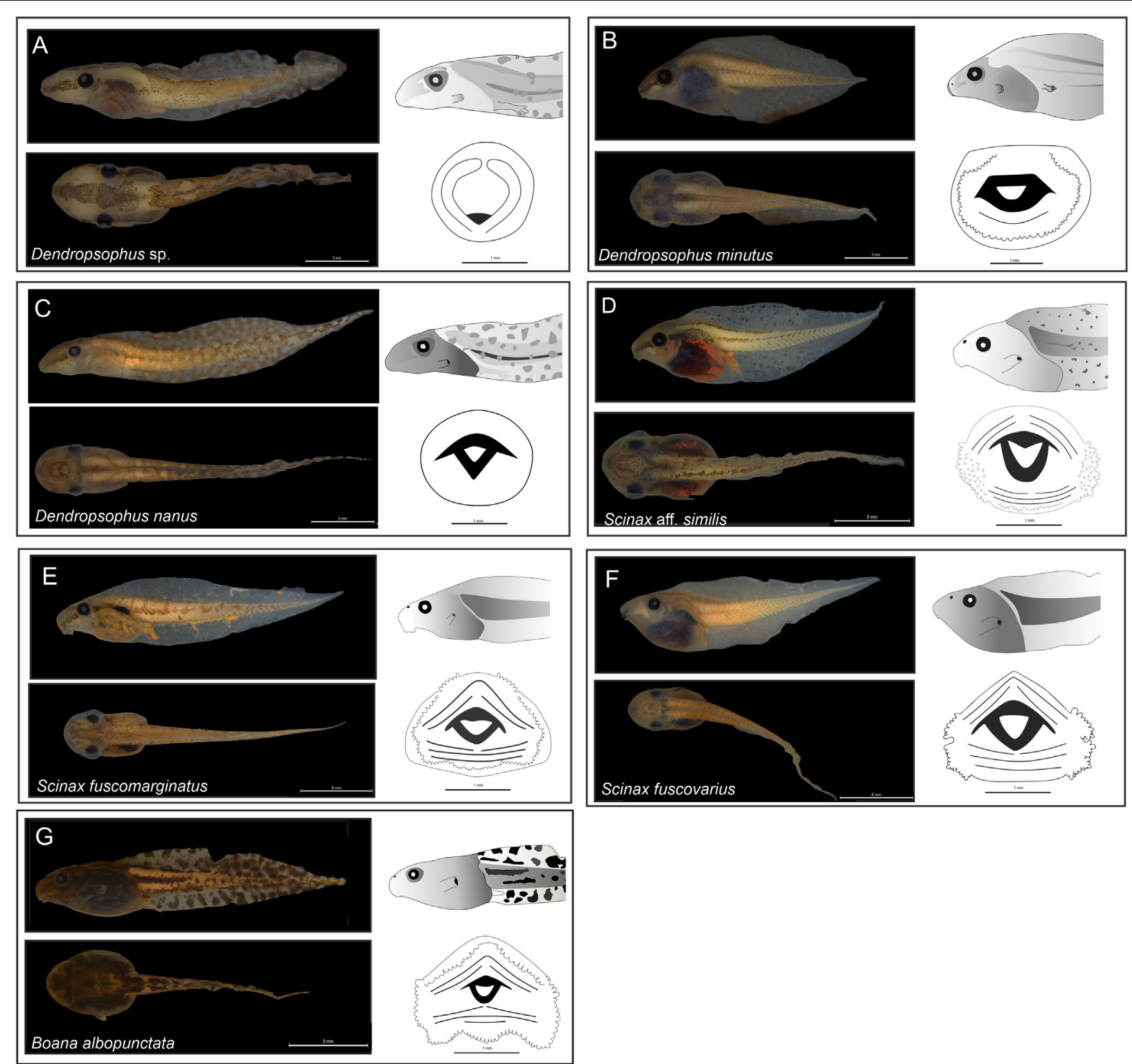

Figure 4. Lateral and dorsal view of hylid tadpoles that occur in the ENP. Schematic drawing to highlight the spiracle and oral disc of tadpoles.

Notes. Some characteristics vary among the populations already described for Boana albopunctata: the origin and height of the dorsal fin, the position of the oral disc, and the shape of the snout, body, and nostrils. The population described by de Sá (1995) presents a planeconvex body in lateral view, snout rounded in dorsal view, eyes directed laterally, and oval nostrils. Rossa-Feres \& Nomura (2006) described a population collected in Nova Itapirema and Vitória Brasil, São Paulo State, Brazil. Those tadpoles differ from the tadpoles that we describe as they have an oval body in dorsal view, eyes directed laterally, nostrils shape oval, lower jaw sheath "V" shaped and dorsal fin with acute emergence angle originating from the tail-body junction. The tadpoles described by Dubeux et al. (2020) present an ovoid body in dorsal view, an acuminate snout in lateral view, eyes directed laterally and dorsal fin originating in the body-tail junction.

\section{Leptodactylidae Werner, 1896}

Leptodactylus labyrinthicus (Spix 1824), figure (5A)

Specimens examined. 10 tadpoles, stages 37 to 39.

Characteristics. Body depressed, elliptical in dorsal view and depressed rounded in lateral view. Snout oval in dorsal view and rounded in lateral view. Eyes dorsal dorsally directed. Nares oval dorsally positioned with opening dorsolaterally directed without projection. Spiracle lateroventral, sinistral, posterodorsally directed, centripetal wall present, fully fused to the body wall. Vent tube medial, with a free distal edge. Oral disc anterior, with keratinized structures, emargination and submarginal papillae absent and marginal papillae present. Tooth row formula 1/2(1). Upper jaw sheath "arc" shaped and lower jaw sheath "V" shaped. Dorsal and ventral fins are low with margin parallel to the longitudinal axis of the tail muscle emerging at 

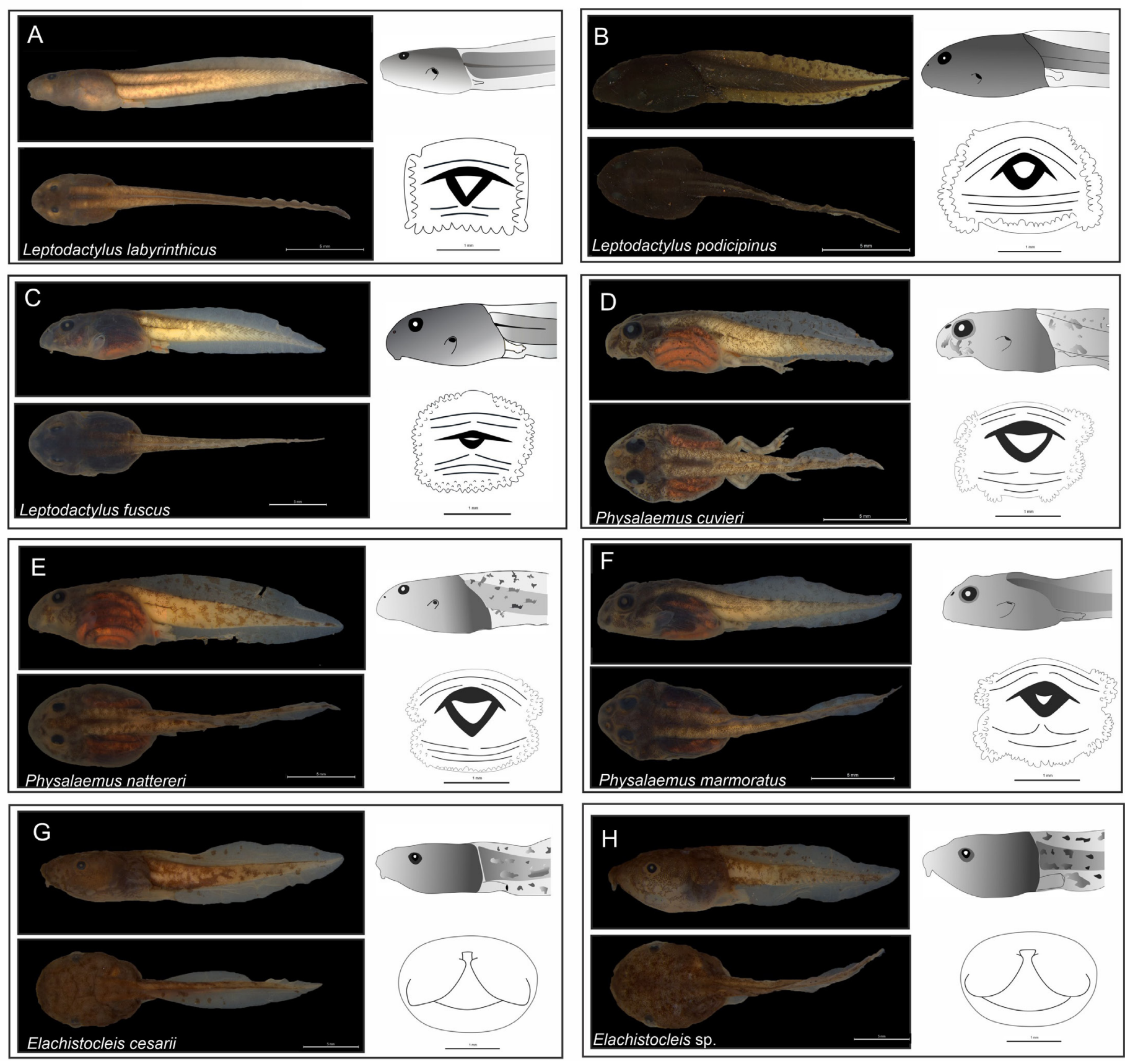

Figure 5. Lateral and dorsal view of leptodactylid and microhylid tadpoles that occur in the ENP. Schematic drawing to highlight the spiracle and oral disc of tadpoles.

ventral tube level. Coloration and muscle tail slightly crosslinked by melanophores, tail with coloration transparent.

Notes. Our tadpoles differ from those described by Rossa-Feres \& Nomura (2006), from the municipality of Nova Itapirema, São Paulo State, Brazil, by the body globular-depressed in lateral view and oval in dorsal view, the rounded snout in dorsal view and the anteroventrally oral disc (stages 36 to 39 ).

Leptodactylus podicipinus (Cope 1862), figure (5B)

Specimens examined. 10 tadpoles, stages 35 to 40 .

Characteristics. Body depressed, ovoid in dorsal view and depressed rounded in lateral view. Snout oval in dorsal view and rounded in lateral view. Eyes dorsal, anterolaterally directed. Nares oval, dorsally positioned with opening laterally directed, without projection.
Spiracle lateroventral, sinistral, posterodorsally directed, centripetal wall fused to the body wall with the free distal edge. Vent tube medial fused to the ventral fin. Oral disc ventral, with keratinized structures, ventral emargination, marginal papillae present and submarginal papillae present. Tooth row formula 2(2)/3. Upper jaw sheath "arc" shaped and lower jaw sheath "V" shaped. Dorsal and ventral fins low with margin parallel to the longitudinal axis of the tail muscle emerging at ventral tube level. Coloration spotted or marbled with angular stains, muscle tail homogeneous coloring, tail with coloration homogeneous.

Notes. Tadpoles from Bolívia (stages 36 and 39, Schulze et al. 2015) had body compressed, elongated-ovoid in dorsal view, snout rounded in dorsal view and "slightly tapering" in lateral view, eyes dorsolaterally directed, and spiracle ventrolateral. The tadpoles (stage 37), described 
by Rossa-Feres \& Nomura (2006) from the northwestern region of São Paulo State, Brazil, had an oral disc positioned anteriorly, eyes positioned dorsolaterally and a sloped snout in view dorsal.

Leptodactylus fuscus (Schneider 1799), figure (5C)

Specimens examined. 10 tadpoles, stages 34 to 37.

Characteristics. Body depressed, elliptical in dorsal view and depressed rounded in lateral view. Snout oval in dorsal view and rounded in lateral view. Eyes dorsal dorsally directed. Nares oval dorsally positioned with opening laterally directed without projection. Spiracle lateroventral, sinistral, posterodorsally directed, centripetal wall present, fully fused to the body wall. Vent tube medial with a free distal edge. Oral disc ventral with keratinized structures, emargination absent, marginal and submarginal papillaes present. Tooth row formula 2(2)/3(1). Upper jaw sheath "arc" shaped and lower jaw sheath "V" shaped. Dorsal fin low with margin slightly convex emerging at ventral tube level. Ventral fin low with margin parallel to the longitudinal axis of the tail muscle emerging at ventral tube level. Coloration slightly crosslinked by melanophores, muscle tail spotted or marbled with angular stains, tail with coloration transparent.

Notes. The population from Nova Itapirema, São Paulo State, Brazil, described by Rossa-Feres \& Nomura (2006), had a depressed globular body in lateral view, oval body in dorsal view, sloped snout in lateral view, eyes directed laterally and anteroventral oral disc. The tadpoles described by Dubeux et al. (2020), collected in the municipality of Macaíba, Rio Grande do Norte State, Brazil (stages 36 to 40), differ by the oval snout in lateral view and the oral disc positioned anteroventrally.

Physalaemus cuvieri Fitzinger 1826, figure (5D)

Specimens examined. 10 tadpoles, stages 34 to 38 .

Characteristics. Body depressed, ovoid in dorsal view and depressed rounded in lateral view. Snout oval in dorsal view and rounded in lateral view. Eyes dorsal anterolaterally directed. Nares oval, dorsally positioned with opening dorsally directed, with a small projection. Spiracle lateral, sinistral, posterodorsally directed, centripetal wall absent. Vent tube medial, entirely fused to ventral fin. Oral disc ventral with keratinized structures, ventral and lateral emargination, marginal and submarginal papillaes present. Tooth row formula 2(2)/3(1). Upper jaw sheath "arc" shaped and lower jaw sheath "V" shaped. Dorsal fin medium with slightly convex margin emerging at ventral tube level, ventral fin low with margin parallel to the longitudinal axis of the tail muscle emerging at ventral tube level. Coloration and muscle tail slightly crosslinked by melanophores, tail with coloration transparent.

Notes. The tadpoles described by Rossa-Feres \& Nomura (2006), collected in the northwest region of São Paulo State, Brazil (stages 37 to 39), differ from the larvae that we describe by the rounded snout in the dorsal view, dorsolateral eyes and dorsal fin with low inclination.

Physalaemus nattereri Steindachner 1863, figure (5E)

Specimens examined. 10 tadpoles, stages 35 to 38 .

Characteristics. Body globular, elliptical in dorsal view and depressed rounded in lateral view. Snout oval in dorsal view and rounded in lateral view. Eyes dorsal anterolaterally directed. Nares circular, dorsally positioned with opening dorsally directed, without projection. Spiracle lateroventral, sinistral, posterodorsally directed, centripetal wall totally fused to the body wall. Vent tube dextral, fused to the ventral fin. Oral disc ventral, with keratinized structures, lateral emargination, marginal and submarginal papillaes present. Tooth row formula 2(2)/3(1). Upper jaw sheath "arc" shaped and lower jaw sheath "V" shaped. Dorsal fin low with margin slightly convex emerging at ventral tube level. Ventral fin low with margin parallel to the longitudinal axis of the tail muscle emerging at ventral tube level. Coloration and muscle tail spotted or marbled with angular stains, tail with coloration transparent.

Notes. The population we describe is very similar to that of two other descriptions, differing only in the shape of the body and snout, and in the direction of the eyes. The tadpoles described by Rossa-Feres \& Nomura (2006), collected in Nova Itapirema, São Paulo State, Brazil (stages 35 to 39 ), had an ovoid body and pointed snout in dorsal view, sloped snout in lateral view, and dorsolateral eyes. The population described by Schulze et al. (2015), collected from San Sebastián and Caparú, Bolivia (stages 37 to 41), had a rounded snout in dorsal view and "slightly tapered" in lateral view.

Physalaemus marmoratus (Reinhardt \& Lütken 1862), figure (5F)

Specimens examined. 10 tadpoles, stages 35 to 37.

Characteristics. Body depressed, ovoid in dorsal view and depressed rounded in lateral view. Snout oval in dorsal view and rounded in lateral view. Eyes dorsal, anterolaterally directed. Nares circular, dorsally positioned with opening dorsally directed. Spiracle lateroventral, sinistral, posterodorsally directed, centripetal wall fused to the body wall. Vent tube medial, fused to the ventral fin. Oral disc ventral with keratinized structures, ventral and lateral emargination, marginal and submarginal papillaes present. Tooth row formula 2(2)/2(1). Upper jaw sheath "arc" shaped and lower jaw sheath "V" shaped. Dorsal fin low with slightly convex margin emerging at anterior third of the tail. Ventral fin low with margin parallel to the longitudinal axis of the tail muscle emerging at ventral tube level. Coloration and muscle tail slightly crosslinked by melanophores, tail with coloration transparent.

Notes. Larvae of this species are very similar to those described by Nomura et al. 2003 and by Rossa-Feres \& Nomura (2006), collected in Nova Itapirema, São Paulo State, Brazil (stages 37 to 40) when the species was still known as Physalaemus fuscomaculatus. The tadpoles differed only in the direction of the eyes, classified as dorsolateral by the authors and in the upper jaw sheath shape, which has an "M" shape.

\section{Microhylidae Günther, 1858}

Elachistocleis cesarii (Miranda-Ribeiro 1920), figure (5G)

Specimens examined. 9 tadpoles, stages 34 and 37.

Characteristics. Body globular, rounded in dorsal view and depressed rounded in lateral view. Snout rounded in dorsal view and truncate in lateral view. Eyes lateral laterally directed. Nares absent. Spiracle ventral with opening dorsally directed and centripetal wall fused to the vent tube. Vent tube ventral, entirely fused to ventral fin. Oral opening anterior with keratinized structures absent, dermal flap with pointed edges, emargination, marginal and submarginal papillaes. Tooth row formula absent. Upper and lower jaw sheath absent. Dorsal fin low with margin parallel to the longitudinal axis of the tail muscle emerging at ventral tube level, ventral fin low with slightly convex margin emerging at ventral tube level. Coloration slightly crosslinked by melanophores, muscle tail spotted or marbled with angular stains, tail with coloration transparent.

Notes. The tadpoles referred to as Elachistocleis cesarii in our study could be the same that were identified as Elachistocleis $\mathrm{cf}$. ovalis in the previous survey carried out by Kopp et al. (2010). The tadpoles described by De Medeiros Magalhães et al. (2012) from the municipality 
of Macaíba, Rio Grande do Norte State, Brazil, had an oval body in lateral and dorsal view. The tadpoles described by Dubeux et al. (2020), also for the municipality of Macaíba, are quite similar to the tadpoles from ENP, differing only in the body shape in lateral view that was considered depressed triangular by the authors.

Elachistocleis sp., Figure $(5 \mathrm{H})$

Specimens examined. 10 tadpoles, stages 34 to 40 .

Characteristics. Body globular, rounded in dorsal view and depressed rounded in lateral view. Snout rounded in dorsal view and truncate in lateral view. Eyes lateral laterally directed. Nares absent. Spiracle ventral, opening dorsally directed with centripetal wall fused to the vent tube. Vent tube ventrally fused to ventral fin with sinister opening and ventral wall longer than the dorsal wall. Oral opening without keratinized structures, dermal flap in front of the oral opening with rounded edges, emargination, marginal and submarginal papillaes absent. Tooth row formula absent. Upper and lower jaw sheaths absent. Dorsal fin low with margin parallel to the longitudinal axis of the tail muscle emerging at the body-tail junction. Ventral fin low with slightly convex margin emerging at ventral tube level. Coloration slightly crosslinked by melanophores, muscle tail spotted or marbled with angular stains, tail with coloration transparent.

Notes. The larvae of Elachistocleis sp. belong to a species not formally described yet (N. Maciel, comm. pers.). In our samples, this tadpole could be morphologically distinguished from the tadpole of Elachistocleis cesarii due to the vent tube opening ventrally, which had a sinistral opening in Elachistocleis sp., and because of the pointed projections in the dermal flap (rounded emarginate in the Elachistocleis sp).

\section{Discussion}

We present characterizations of the external morphology for larvae of 15 species of anurans and an updated list of anurans in the larval phase that occurs in the ENP. The tadpoles associated with the species Leptodactylus sertanejo was excluded from the study because we collected only one individual. Five species represent new records for the park. We found a high morphological diversity for tadpoles in ENP, with larvae represented in five of the 15 exotrophic ecomorphological guilds (sensu Altig \& McDiarmid 1999): benthic, macrophagous, carnivore, suspension feeder, and nektonic tadpoles. Many species had variations in morphological traits when compared with descriptions available for other locations, reinforcing the importance of describing larvae from different populations.

\section{Morphological characterization}

Our knowledge about tadpoles' morphological diversity has advanced in the last 20 years, but there is still much more to explore. Several species remain with no formal description of the larval phase or the morphology, and the understanding of geographic, ontogenetic and metamorphic variation is still scarce, especially in the Neotropics (Altig \& McDiarmid 1999; Provete et al. 2012). We found that the height of the fins, the direction of the eyes, and the shape of the body and nostrils were the morphological traits that had more variation among populations. The number of rows of denticles, the position of the spiracle, and the position of the vent tube varied for only a few species.

The microhabitat and environmental heterogeneity may explain part of the observed variation in the tadpoles' morphological traits that we found. Most of the articles that we used to compare external morphology among populations are from larvae collected in the Atlantic Forest (e.g. De Medeiros Magalhães et al. 2012, Dubeux et al. 2020). Thus, tadpoles exposed to specific selective pressures may present variations in morphological characteristics throughout the species distribution (Gatz 1979).

Conversely, the variation in the morphological traits found in species with wide distribution may denote a complex of cryptic species, as in the case of Scinax aff. similis. For this species, the number of denticle rows is considered a diagnostic character between species and relatively well maintained evolutionarily (Altig \& McDiarmid 1999, Candioti 2007). These traits varied among all populations for which the tadpole's description is available.

\section{Species survey}

The species accumulation curve showed that we found fewer species than expected, which may be related to the use of only one sampling method for the survey. Kopp et al. (2010), for example, surveyed the anurofauna in the ENP region using sampling of adults and larvae and recorded 25 species (14 in the larval phase). Here, we only sampled anurans in the larval phase, which may explain the smaller number of species. Besides, our sampling was performed only in the rainy season, while Kopp et al. (2010) sampled both in the rainy and dry seasons, which increases the chance of sampling of anuran species that breed at different seasons of the year.

Although we collected anurans only in the larval phase, and we have limitations in our collection method related to sampling in the deepest portions of the ponds, we recorded for the first time the occurrence of Dendropsophus nanus, Scinax aff. similis, Physalaemus marmoratus, Elachistocleis sp. and Elachistocleis cesarii in the ENP. Among the larval anurans found by Kopp et al. (2010), we did not find Rhinella schneideri (Werner 1894), Leptodactylus furnarius Sazima \& Bokermann, 1978, Pseudopaludicola aff. falcipes and Pseudopaludicola cf. mystacalis. The tadpoles' referred to as Elachistocleis sp. is the larval phase of a probably new species (N. Maciel, comm. pers.).

Larval sampling can increase the detectability of different species, as demonstrated in the following studies (Table 1). Considering species

Table 1. Faunistic surveys that registered anurans in adult and larval phases.

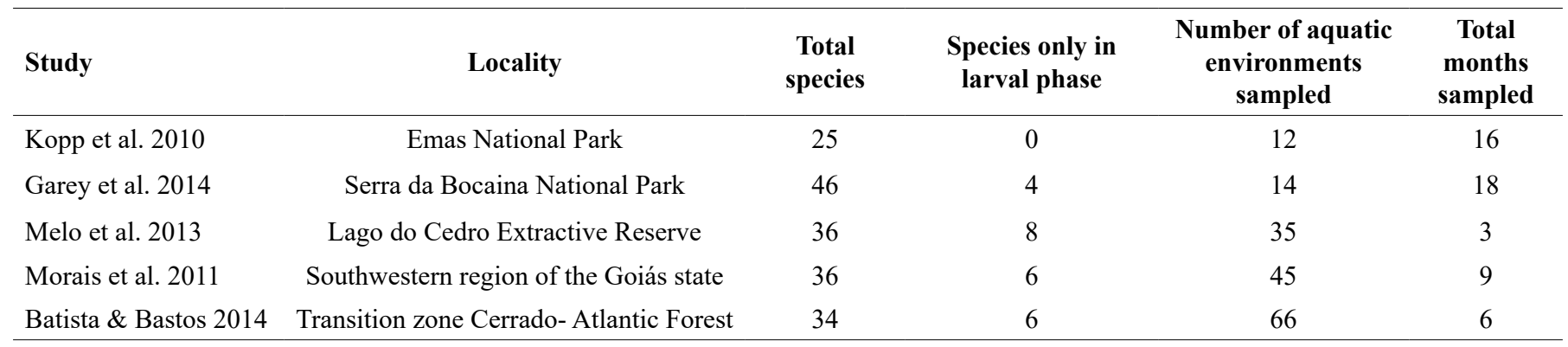


found exclusively in the larval phase, Melo et al. (2013) found eight of 36 species (Lago do Cedro Extractive Reserve), Morais et al. (2011) found six of 36 (southwestern region of Goiás State), Batista \& Bastos (2014) found six of the 34 species (transition zone at the CerradoAtlantic Forest), while Garey et al. (2014), in the Atlantic Forest Biome (Serra da Bocaina National Park), found four of the 46 species registered. On the other hand, Kopp et al. (2010) found 25 anurans species at ENP, but none was found exclusively in the larval stage. Thus, surveys can potentially increase the detection of anurans and produce more accurate species lists, as long as they are combined with information obtained from surveys of adults, larvae and acoustic information (Silva 2010). In addition, we highlight the importance of standardizing the collection method and the sampling effort to facilitate the comparisons among surveys. For studies that focus on anuran tadpoles surveys, the sampling method must be well planned to overcome the challenges of finding the larval of anuran, as pond depth and vegetation association.

The sampling of tadpoles can provide important information both for delimiting the geographic distribution of anurans and for increasing understanding of their morphological diversity (Altig \& McDiarmid 1999). Despite the increase in research on tadpoles in the last decade, information on distribution patterns, natural history, ecology and morphological diversity of the larvae are still scarce (Provete et al. 2012, Rossa-Feres et al. 2015). By investing in basic biodiversity research, we can generate more accurate models on the determinants of anurans' richness and distribution, and provide support for proposing more consistent conservation strategies and management plans.

\section{Supplementary Material}

The following online material is available for this article:

Table S1. Characterization of sites sampled at ENP and surroundings. High: vegetation cover $\geq 70 \%$; Low: vegetation cover $<70 \%$. PD refers to the sites located within ENP. PE refers to sites located in the vicinity of ENP.

Table S2. Voucher number of anurans in larval phase registered from Emas National Park.

Table S3. Abundance and richness by sampling locality. Species abbreviations: Dendropsophus minutus (Dm), Dendropsophus nanus (Dn), Dendropsophus sp. (Dsp), Elachistocleis cesarii (Ec), Elachistocleis sp. (Esp), Boana albopunctata (Bal), Leptodactylus fuscus (Lf), Leptodactylus labyrinthicus (Ll), Leptodactylus podicipinus (Lp), Physalaemus nattereri (Pn), Physalaemus cuvieri (Pc), Physalaemus marmoratus (Pm), Scinax fuscomarginatus (Sfm), Scinax fuscovarius (Sf) and Scinax aff. similis (Saffs).

\section{Acknowledgements}

G.A.F thanks the Undergraduate Research Internship Program (PIVIC) for the support to carry out this work. We thanks funding by Conselho Nacional de Desenvolvimento Científico e Tecnológico - CNPq (301232/2018-0 and 420051/2016-3) and the PELD (Long-Term Ecological Research Program CNPq/FAPEG 441276/2020-2, 441214/2016-9). We acknowledge MSc. F. Fava, MSc. O. Rojas-Padilla, Dr. L. Signorelli, MSc. M. Melo, Dr. N. Maciel, MSc. A. Valencia, Dr. C. Moreno, Dr. D. Fortunato and two anonymous reviewers for their insightful comments and suggestions. We are also grateful to the entire field team that assisted in the tadpole's sampling. We thank Dr. N. Nagatani Dias for the help with the Scinax taxonomy and MSc. P. Cabral for the manuscript translation. The present study was utilized as the final work of G.A.F. to obtain the graduate degree in Ecology and Environmental Analysis at the Federal University of Goiás. Collection permission was given by IBAMA n ${ }^{\circ} 41174-2$.

\section{Author Contributions}

Gabriela Alves-Ferreira: Substantial contribution in the concept and design of the study; Contribution to data collection; Contribution to data analysis and interpretation; Contribution to manuscript preparation; Contribution to critical revision, adding intellectual content.

Ingrid B. Ferreira da Paixão: Substantial contribution in the concept and design of the study; Contribution to data collection; Contribution to data analysis and interpretation; Contribution to manuscript preparation; Contribution to critical revision, adding intellectual content.

Fausto Nomura: Substantial contribution in the concept and design of the study; Contribution to data collection; Contribution to data analysis and interpretation; Contribution to manuscript preparation; Contribution to critical revision, adding intellectual content.

\section{Conflicts of interest}

The authors declares that they have no conflict of interest related to the publication of this manuscript.

\section{References}

ALTIG \& MCDIARMID. 1999. Body plan: development and morphology. In Tadpoles: The Biology of Anuran Larvae p.24-51.

ALTIG, R. 1970. A key to the tadpoles of the continental United States and Canada. Herpetologica.

ALTIG, R. \& JOHNSTON, G.F. 1989. Guilds of Anuran Larvae: Relationships among Developmental Modes, Morphologies, and Habitats. Herpetol. Monogr. 381.

ALVES, A.C. \& CARVALHO E SILVA, S.P. de. 1999. Descrição da larva de Scinax similis (Cochran) com notas comparativas sobre o grupo "ruber" no sudeste do Brasil (Amphibia, Anura, Hylidae). Rev. Bras. Zool. 16(2):507-512.

BATISTA, V.G. \& BASTOS, R.P. 2014. Anurans from a Cerrado-Atlantic Forest ecotone in Campos Gerais region, southern Brazil. Check List 10(3):574-582.

CULLEN, L. JR., RUDRAN, R. \& VALLADARES-PÁDUA, C. 2012. Métodos de Estudos em Biologia da Conservação e Manejo da Vida Silvestre. $2^{\mathrm{a}}$ ed. UFPR.

CANDIOTI, M.F.V. 2007. Anatomy of anuran tadpoles from lentic water bodies: systematic relevance and correlation with feeding habits. Zootaxa 1600(1):1-175.

COLWELL, R.K. 2016. Estimates: Statistical estimation of species richness and shared species from samples.

COLWELL, R.K., MAO, C.X. \& CHANG, J. 2004. Interpolating, extrapolating, and comparing incidence-based species accumulation curves. Ecology 85(10):2717-2727.

DE MEDEIROS MAGALHÃES, F., SANTANA, Di.J., NETO, A.M. \& GARDA, A.A. 2012. The tadpole of Elachistocleis cesarii Miranda-Ribeiro, 1920 (Anura, Microhylidae). Zootaxa 3187(1):54.

DUBEUX, M.J.M., NASCIMENTO, F.A.C. do, LIMA, L.R., MAGALHÃES, F. de M., SILVA, I.R.S. da, GONÇALVES, U., ALMEIDA, J.P.F., CORREIA, L.L., GARDA, A.A., MESQUITA, D.O., ROSSA-FERES, D. de C. \& MOTT, T. 2020. Morphological characterization and taxonomic key of tadpoles (Amphibia: Anura) from the northern region of the Atlantic Forest. Biota Neotrop. 20(2). 
DUELLMAN, W. \& TRUEB, L. 1994. Biology of Amphibia. The Johns Hopkins University Press.

FROST, D. 2020. Amphibian Species of the World: an online reference. Am. Museum Nat. Hitory.

GAREY, M. V., PROVETE, D.B., MARTINS, I.A., HADDAD, C.F.B. \& ROSSA-FERES, D.C. 2014. Anurans from the Serra da Bocaina National Park and surrounding buffer area, southeastern Brazil. Check List 10(2):308.

GATZ, J. 1979. Ecological morphology of freshwater stream fishes. Tulane Stud. Zool. Bot. 2191-124.

GEHARA, M. et al. 2014. High Levels of Diversity Uncovered in a Widespread Nominal Taxon: Continental Phylogeography of the Neotropical Tree Frog Dendropsophus minutus PLoS One 9(9):e103958.

GOSNER, K.L. 1960. A simplified table for staging anuran embryos and larvae with notes on identification. Herpetologica 5(3):183-190.

GOTELLI, N.J. \& COLWELL, R.K. 2001. Quantifying biodiversity: Procedures and pitfalls in the measurement and comparison of species richness. Ecol. Lett. 4(4):379-391.

GROSJEAN, S. 2005. The choice of external morphological characters and developmental stages for tadpole-based anuran taxonomy: a case study in Rana (Sylvirana) nigrovittata (Blyth, 1855) (Amphibia, Anura, Ranidae). Contrib. to Zool. 74(1-2):61-76.

GUARINO R. COLLI, R.P.B. and A.F.B.A. 2002. The Character and Dynamics of the Cerrado Herpetofauna. Ecol. Nat. Hist. Neotrop. savanna 223-241.

IBDF. 1981. Parque Nacional das Emas - Plano de Manejo.

KOPP, K., SIGNORELLI, L. \& BASTOS, R.P. 2010. Distribuição temporal e diversidade de modos reprodutivos de anfíbios anuros no Parque Nacional das Emas e entorno, Estado de Goiás, Brasil. Iheringia. Série Zool. 100(3):192-200.

LANDE, R., DEVRIES, P.J. \& WALLA, T.R. 2000. When species accumulation curves intersect: implications for ranking diversity using small samples. Oikos 89(3):601-605.

LIND, M.I. \& JOHANSSON, F. 2007. The degree of adaptive phenotypic plasticity is correlated with the spatial environmental heterogeneity experienced by island populations of Rana temporaria. J. Evol. Biol. 20(4):1288-1297.

LIPS, K.R. \& SAVAGE, J.M. 1996. Key to the Known Tadpoles (Amphibia: Anura) of Costa Rica. Stud. Neotrop. Fauna Environ. 31(1):17-26.

MADALOZZO, B., SANTOS, T.G., SANTOS, M.B., BOTH, C. \& CECHIN, S. 2017. Biodiversity assessment: selecting sampling techniques to access anuran diversity in grassland ecosystems. Wildl. Res. 44(1):78.

MARQUES, N.C.S., FAVA, F.G. \& NOMURA, F. 2019. MorphologyEnvironment Interaction in Ecomorphological Guilds of Tadpoles. South Am. J. Herpetol. 14(2):116.

MARQUES, N.C.S. \& NOMURA, F. 2018. Environmental and spatial factors affect the composition and morphology of tadpole assemblages. Can. J. Zool. 96(10):1130-1136.

MARQUES, N.C.S., RATTIS, L. \& NOMURA, F. 2019. Local environmental conditions affecting anuran tadpoles' microhabitat choice and morphological adaptation. Mar. Freshw. Res. 70(3):395.

MASCARENHAS, L., TISO, C., LINARES, A.M., DE MOURA, C.F.O., PEZZUTI, T.L., LEITE, F.S.F. \& ETEROVICK, P.C. 2016. Improved local inventory and regional contextualization for anuran (Amphibia) diversity assessment at an endangered habitat in southeastern Brazil. J. Nat. Hist. 50(19-20):1265-1281.
NOMURA, F., ROSSA-FERES, D.D.C. \& PRADO, V.H.M. 2003. O girino de Physalaemus fuscomaculatus (Anura: Leptodactylidae), com uma descrição da morfologia oral interna. Zootaxa 370 1-8.

MELO, M., FAVA, F., PINTO, H.B.A., BASTOS, R.P. \& NOMURA, F. 2013. Diversidade de Anuros (Amphibia) na reserva extrativista Lago do Cedro e seu entorno, Aruanã, Goiás. Biota Neotrop. 13(2):205-217.

MORAIS, A.R., SIGNORELLI, L., GAMBALE, P.G., KOPP, K., NOMURA, F., GUIMARÃES, L.D., VAZ-SILVA, W., RAMOS, J. \& BASTOS, R.P 2011. Anfíbios anuros associados a corpos d'água do sudoeste do estado de Goiás, Brasil. Biota Neotrop. 11(3):355-363.

PEZZUTI, T.L. 2011. Girinos do quadrilátero ferrífero, sudeste do Brasil: ecomorfologia e chave de identificação interativa. Universidade Federal de Minas Gerais.

PROVETE, D.B., GAREY, M.V., DA SILVA, F.R. \& JORDANI, M.X. 2012. Knowledge gaps and bibliographical revision about descriptions of freeswimming anuran larvae from Brazil. North. West. J. Zool. 8(2):283-286.

RAMOS-NETO, M.B. \& PIVELLO, V.R. 2000. Lightning Fires in a Brazilian Savanna National Park: Rethinking Management Strategies. Environ. Manage. 26(6):675-684.

ROSSA-FERES, D. de C., VENESKY, M.D., NOMURA, F., ETEROVICK, P.C., CANDIOTI, M.F.V., MENIN, M., JUNCÁ, F.A., SCHIESARI, L.C., HADDAD, C.F., GAREY, M. V., DOS ANJOS, L.A. \& WASSERSUG, R. 2015. Taking tadpole biology into the 21 st century: a consensus paper from the First Tadpoles International Workshop. Herpetol. Bras. 4(2):48-59.

ROSSA-FERES, D.D.C. \& NOMURA, F. 2006. Characterization and taxonomic key for tadpoles (Amphibia : Anura ) from the northwestern region of São Paulo State, Brazil 1. Biota Neotrop. 6.

SÁ, R.O. De. 1995. Hyla albopunctata Spix, 1824. Cat. Am. Amphib. Reptil. 602.1-602.5.

SCHULZE, A., JANSEN, M. \& KOHLER, G. 2015. Tadpole diversity of Bolivia's lowland anuran communities: molecular identification, morphological characterisation, and ecological assignment. Zootaxa 4016(1):1.

SILVA, F.R. Da. 2010. Evaluation of Survey Methods for Sampling Anuran Species Richness in the Neotropics. South Am. J. Herpetol. 5(3):212-220.

VALDUJO, P.H., SILVANO, D.L., COLLI, G. \& MARTINS, M. 2012. Anuran Species Composition and Distribution Patterns in Brazilian Cerrado, a Neotropical Hotspot. South Am. J. Herpetol. 7(2):63-78.

VAZ-SILVA, W., MACIEL, N.M., NOMURA, F., MORAIS, A.R. de, BATISTA, V.G., SANTOS, D.L., ANDRADE, S.P., OLIVEIRA, A.Â.B. de, BRANDÃO, R.A. \& BASTOS, R.P. 2020. Guia de identificação das espécies de anfíbios (Anura e Gymnophiona) do estado de Goiás e do Distrito Federal, Brasil Central. Sociedade Brasileira de Zoologia.

VENCES, M., ANDREONE, F., GLOS, J. \& GLAW, F. 2010. Molecular and bioacoustic differentiation of Boophis occidentalis with description of a new treefrog from north-western Madagascar. Zootaxa 2544(1):54.

WALTHER, B.A. \& MORAND, S. 1998. Comparative performance of species richness estimation methods. Parasitology 116(4):395-405.

Received: 11/12/2020

Revised: 02/07/2021

Accepted: 05/07/2021

Published online: 23/07/2021 